\title{
Pemetaan Jumlah Property Crime di Provinsi Jawa Timur Menggunakan Metode Geographically Weighted Negative Binomial Regression (GWNBR) dan Geographically Weighted Poisson Regression (GWPR)
}

\author{
Bagas Wahyu Yoga Priambodo dan Irhamah \\ Departemen Statistika, FMKSD, Institut Teknologi Sepuluh Nopember (ITS) \\ J1. Arief Rahman Hakim, Surabaya 60111 Indonesia \\ e-mail:irhamah@statistika.its.ac.id
}

\begin{abstract}
Abstrak-Kriminal merupakan suatu kegiatan yang melanggar hukum. Ada beberapa faktor yang mempengaruhi para kriminal melakukan tindakan kejahatan antara lain kemiskinan, kesempatan kerja, dan karakter pelaku yang melakukan kejahatan. Selain itu ada pula faktor lain yang mempengaruhi timbulnya kejahatan yaitu kepadatan penduduk, jumlah patroli polisi, keadaan jalan dan lingkungan, frekuensi ronda siskamling, dan faktor lainnya. Property crime merupakan kategori kejahatan yang termasuk di dalamnya yaitu pencurian, pengambilan sesuatu yang melanggar hukum, perampokan, kejahatan dengan pembakaran, dan perusakan properti. Seringkali kejadian kriminalitas akan saling berdampak dari satu wilayah ke wilayah yang lainnya. Untuk menyelesaikan kasus tersebut diperlukan suatu pemodelan dengan metode spasial kerena memperhatikan kondisi geografis yang ada di provinsi Jawa Timur. Pemodelan dengan memperhatikan faktor spasial menggunakan GWNBR dan GWPR, dimana setiap wilayah pasti memiliki kondisi geografis yang berbeda sehingga menyebabkan adanya perbedaan jumlah Property crime antara wilayah satu dengan wilayah yang lainnya sesuai dengan karakteristik wilayah tersebut. Hasil pemodelan dengan metode GWNBR terbentuk dua kelompok kabupaten/kota menurut variabel yang berpengaruh signifikan terhadap jumlah kasus Property crime. Hasil pemodelan dengan metode GWPR menunjukkan bahwa kelompok kabupaten/kota menurut variabel yang berpengaruh signifikan terhadap jumlah kasus Property crime sebanyak 16 kelompok. Berdasarkan kriteria AIC terkecil menunjukkan bahwa metode GWNBR merupakan metode yang paling sesuai untuk memodelkan jumlah kasus Property crime setiap kabupaten/kota di Jawa Timur dibandingkan dengan metode regresi Poisson, regresi binomial negatif, dan GWPR.

Kata Kunci-Geographically Weighted Negative Binomial Regression, Geographically Weighted Poisson Regression, Kejahatan, Property Crime.
\end{abstract}

\section{PENDAHULUAN}

$\mathrm{T}$ indakan kriminal merupakan suatu kegiatan yang melanggar hukum dan tidak sesuai dengan peraturan dan norma yang berlaku dalam suatu masyarakat. Ahli kriminologi beranggapan bahwa perilaku menyimpang disebut sebagai kejahatan yang harus dijelaskan dengan melihat kondisi struktural dalam masyarakat dalam konteks ketidakmerataan kekuasaan, otoritas, dan kemakmuran serta kaitannya dengan berbagai perubahan ekonomi dan politik yang ada di masyarakat [1]. Ada beberapa faktor yang mempengaruhi para kriminal melakukan tindakan kejahatan antara lain pendidikan, kesempatan kerja, dan karakter pelaku yang melakukan kejahatan [2]. Selain itu ada pula faktor lain yang mempengaruhi timbulnya kejahatan yaitu kepadatan penduduk, jumlah patroli polisi, keadaan lingkungan, dan frekuensi ronda siskamling [3].

Property crime merupakan kategori kejahatan yang termasuk di dalamnya antara lain pencurian, pengambilan sesuatu yang melanggar hukum, perampokan, pencurian kendaraan bermotor, kejahatan dengan pembakaran, dan perusakan properti. Segala kejahatan yang dilakukan dalam rangka untuk memperkaya pelaku, maka dianggap Property crime [4]. Selain faktor ekonomi, ada faktor lain yang ikut berdampak yaitu pendidikan. Orang yang tergolong miskin akan identik dengan memiliki pendidikan yang rendah. Sehingga memungkinkan untuk melakukan kejahatan agar memenuhi kebutuhan sehari-hari [5].

Analisis regresi merupakan metode untuk menentukan adanya hubungan sebab akibat antara satu variabel dengan variabel yang lainnya. Salah satu contoh kondisi ketika data variabel respon adalah data cacah dengan sebaran distribusi Poisson maka regresi Poisson menjadi cocok untuk digunakan. Akan tetapi, regresi Poisson mempunyai asumsi yang harus dipenuhi sebelum digunakan yaitu rata-rata variabel respon harus sama dengan variansinya yang dikenal dengan sebutan equidispersi [6]. Geographically Weighted Poisson Regression (GWPR) merupakan suatu metode statistika yang merupakan pengembangan dari regresi poisson namun yang membedakan adalah dalam metode ini memperhatikan pembobot berupa letak lintang dan letak bujur dari wilayah-wilayah yang diamati [7]. Geographically Weighted Negative Binomial Regression (GWNBR) adalah salah satu metode yang dapat digunakan untuk membentuk analisis regresi yang bersifat lokal pada setiap lokasi pengamatan [8].

Pada penelitian ini digunakan metode GWNBR dan GWPR dengan unit penelitian 38 kabupaten/kota di provinsi Jawa Timur. Hasil analisis yang akan dihasilkan Antara lain model regresi Poisson, model regresi negatif binomial, model GWNBR dan model GWPR serta model mana yang paling baik untuk memodelkan Property crime di provinsi Jawa Timur. Model yang dibentuk menggunakan pembobot fix Gaussin Kernel.

\section{TINJAUAN PUSTAKA}

\section{A. Konsep Property Crime}

Secara yuridis, kejahatan dapat diartikan sebagai suatu perbuatan atau tingkah laku yang bertentangan dengan undang-undang [9]. The Federal Bureau of Investigation 
(FBI) membagi kejahatan menjadi 2 tipe, yaitu kejahatan kekerasan dan kejahatan property (Property crime) [10]. Kejahatan kekerasan merupakan kejahatan dengan adanya tindak kekerasan. Sedangkan kejahatan properti adalah segala tindak kejahatan yang menjadikan harta benda sebagai objeknya. Kejahatan tipe ini biasanya dilakukan dengan sembunyi-sembunyi, tidak menggunakan kekerasan, serta direncanakan dengan perhitungan yang rasional.

Melihat pada kasus di Provinsi Jawa Timur, perampokan yang menggunakan kekerasan fisik juga dikategroikan sebagai kejahatan properti. Hal ini disebabkan karena kebanyakan kasus perampokan di Provinsi Jawa Timur didominasi oleh motif ekonomi, berbeda dengan definisi di Amerika Serikat. Berdasarkan kasus yang terjadi di Provinsi Jawa Timur, maka kejahatan properti yang didefinisikan pada penelitian ini adalah pencurian, pencurian dengan kekerasan, penadahan, pengrusakan atau penghancuran barang, dan pembakaran barang dengan sengaja.

\section{B. Peta Tematik}

Peta tematik merupakan gambaran dari sebagian permukaan bumi yang dilengkapi dengan informasi yang mengandung tema tertentu yang berupa data kualitatif maupun kuantitatif. Peta tematik mempunyai hubungan atau hampir sama dengan SIG atau Sistem Informasi Geografis. Itu disebabkan karena pada umumnya hasil dari proyek SIG berupa peta tematik [11]. Pengelompokan pada peta tematik mempunyai berbagai macam metode yang bisa digunakan. Salah satu metode tersebut adalah dengan menggunakan metode Natural Break. Metode Natrual Break akan menghasilkan variasi minimum untuk wilayah yang berada pada satu kelompk tema tertentu. Berikut merupakan langkahlangkah atau algoritma yang digunakan untuk melakukan metode Natural Break.

1. Bagi daerah menjadi sebanyak $h$ kelompok dari $n$ wilayah. Banyak wilayah anggota setiap kelompok minimal 1 dan maksimal n-(q-1).

2. Hitung rata-rata data setiap kelompok. Hasil rata-rata dilambangkan dengan

3. Hitung jumlahan standar deviasi kuadrat dari setiap kelompok kombinasi wilayah.

Pembagian kelompok dengan jumlahan standar deviasi kuadrat terkecil adalah pembagian wilayah yang optimum.

\section{Pemeriksaaan Multikolinieritas}

Multikolinieritas terjadi jika adanya korelasi antar variabel prediktor dalam model regresi linier. Kejadian multikolinieritas akan menyebabkan kesalahan yang besar pada penduga parameter regresi. Sehingga menyebabkan hasil penduga parameter bias dan tidak baik untuk dianalisis lebih lanjut. Oleh sebab itu, perlu dilakukan pemeriksaan multikolinieritas agar hasil penduga parameter tersebut bisa dianalisis lebih lanjut [12]. Pemeriksaan multikolinieritas dapat dilakukan melalui perhitungan nilai koefisien korelasi Pearson (ril) antar variabel prediktor. Jika nilai nilai koefisien korelasi Pearson (ril) antar variabel prediktor lebih besar dari 0,95 maka terjadi multikolinieritas dalam model tersebut. Selain dengan nilai koefisien korelasi Pearson (ril), pemeriksaan multikolinieritas dapat dilakukan melalui nilai Variance Inflation Faktors (VIF). Untuk mendapatkan nilai
Variance Inflation Faktors (VIF), bisa dilihat pada rumus berikut ini.

$$
V I F_{J}=\frac{1}{1-R_{j}^{2}}
$$

Dimana $R_{j}^{2}$ adalah koefisien determinasi antara $\mathrm{X}_{\mathrm{j}}$ dengan variabel prediktor lainnya. Jika nilai VIF lebih besar dari 5, maka model tersebut telah terjadi multikolinieritas. Solusi untuk mengatasi adanya kasus multikolinieritas yaitu dengan mengeluarkan variabel prediktor yang tidak signifikan dalam model dengan forward selection [12]. Metode forward selection dilakukan dengan cara memasukkan variabel prediktor secara bertahap. Variabel prediktor ini dimasukkan ke dalam model berdasarkan korelasi parsial terbesar. Variabel prediktor yang akan masuk model akan diregresikan dengan variabel respon. Variabel prediktor yang dimasukkan ke dalam model tidak akan dapat dikeluarkan lagi. Proses tersebut akan dihentikan ketika variabel prediktor yang akan dimasukkan ke dalam model tidak berpengaruh secara signifikan terhadap variable respon.

\section{Pemilihan Model Terbaik}

Kriteria yang digunakan untuk memilih model regresi terbaik adalah Akaike Information Criterion (AIC). AIC merupakan kriteria yang digunakan untuk memilih model terbaik yang didefinisikan sebagai berikut:

$$
A I C=-2 \ln L(\beta)+2 K
$$

dimana $\ln L(\boldsymbol{\beta})$ merupakan nilai likelihood dan $\mathrm{K}$ merupakan jumlah parameter dalam model. Model terbaik adalah model yang memiliki nilai AIC terkecil.

\section{E. Regresi Poisson}

Distribusi Poisson adalah distribusi probabilitas acak yang menyatakan banyaknya sukses dari suatu percobaan dengan distribusi probabilitasnya merupakan distribusi poisson [13]. Regresi Poisson merupakan model regresi nonlinier yang digunakan untuk jenis data count dimana variabel respon mengikuti distribusi Poisson [14]. Model regresi Poisson menggunakan fungsi $\log$ yaitu $\ln \left(\mu_{i}\right)=\eta_{i}$. Jika variabel bebas $x_{1}, x_{2}, \ldots, x_{k}$, maka fungsi hubungan untuk model regresi Poisson pada pengamatan ke-i didefinisikan seperti persamaan dibawah ini.

$$
\ln \left(\mu_{i}\right)=\beta_{0}+\beta_{1} x_{1 i}+\beta_{2} x_{2 i}+\ldots+\beta_{k} x_{k i}
$$

\section{Estimasi Parameter}

Penaksir parameter regresi Poisson dilakukan dengan metode Maximum Likelihood Estimation (MLE). Metode Maximum Likelihood Estimation (MLE) dilakukan dengan menurunkan parsial fungsi ln-likelihood pada parameter yang akan ditaksir [15]. Berikut ini merupakan bentuk umum dari fungsi ln-likelihood untuk regresi Poisson.

$$
\begin{aligned}
L(\boldsymbol{\beta}) & =\prod_{i=1}^{n} f\left(y_{i}, \boldsymbol{\beta}\right) \\
& =\prod_{i=1}^{n}\left\{\frac{\left[\mu\left(\mathbf{x}_{i}, \boldsymbol{\beta}\right)\right]^{y_{i}} \exp \left[-\mu\left(\mathbf{x}_{i}, \boldsymbol{\beta}\right)\right]}{y_{i} !}\right\}
\end{aligned}
$$

Selanjutnya adalah menurunkan fungsi ln-likelihood pada persamaan diatas terhadap parameter yang akan ditaksir yaitu $\boldsymbol{\beta}$, kemudian persamaan tersebut disamakan 
dengan nol. Persamaan tersebut merupakan persamaan yang masih berbentuk implisit sehingga alternatif lain yang dapat digunakan untuk menentukan nilai prosedur MLE adalah menggunakan metode iterasi numerik yaitu NewtonRaphson.

2. Pengujian Secara Serentak

Pengujian signifikansi parameter model regresi poisson secara serentak dengan menggunakan Maximum Likelihood Ratio Test (MLRT) dengan hipotesis sebagai berikut:

$\mathrm{H}_{0}: \beta_{1}=\beta_{2}=\cdots=\beta_{p}=0$

$\mathrm{H}_{1}$ : paling sedikit ada satu $\beta_{\mathrm{k}} \neq 0$ dimana $\mathrm{k}=1,2, \ldots, \mathrm{p}$. Statistik uji :

$$
D(\widehat{\beta})=-2 \ln \left(\frac{L(\widehat{\omega})}{L(\widehat{\Omega})}\right)=2(\ln L(\widehat{\Omega})-\ln L(\widehat{\omega})
$$

Daerah penolakan : Tolak $\mathrm{H}_{0}$ jika statistik uji nilai $D(\widehat{\beta})>\chi^{2}{ }_{(p ; \alpha)}$.

3. Pengujian Secara Parsial

Pengujian parameter secara parsial dilakukan untuk mengetahui parameter pada variabel mana saja yang memberikan pengaruh secara signifikan terhadap variabel respon pada tiap-tiap lokasi dengan hipotesis seperti dibawah ini.

$$
\begin{aligned}
& \mathrm{H}_{0}: \beta_{k}=0 \\
& \mathrm{H}_{1}: \beta_{k} \neq 0
\end{aligned}
$$

Statistik uji :

$$
Z=\frac{\widehat{\beta}_{k}}{\operatorname{se}\left(\hat{\beta}_{k}\right)}
$$

Daerah penolakan : Tolak $\mathrm{H}_{0}$ jika $|Z|>Z_{\alpha / 2}$

\section{F. Overdispersi}

Regresi Poisson dikatakan overdispersi apabila nilai variansnya lebih besar dari nilai rata-ratanya. Jika pada data diskrit terjadi overdispersi dan tetap menggunakan regresi Poisson sebagai metode penyelesaiannya, maka akan diperoleh suatu kesimpulan yang tidak valid karena nilai standart error menjadi under estimate. Hal ini disebabkan karena parameter koefisien regresi yang dihasilkan dari regresi Poisson tidak efisien meskipun koefisien regresinya tetap konsisten. Overdipersi [16] dapat dituliskan seperti dibawah ini.

$$
\operatorname{Var}(Y)>E(Y)
$$

Overdispersi dapat dideteksi dengan nilai dispersi pearson Chi-square atau deviance yang dibagi dengan derajat bebasnya, diperoleh nilai lebih besar dari 1. Parameter untuk overdispersi biasa dilambangkan dengan simbol $\theta$. Jika $\theta>1$ artinya terjadi overdispersi pada regresi Poisson, jika $\theta<1$ artinya terjadi underdispersi dan jika $\theta=1$ berarti tidak terjadi kasus over/under dispersi yang disebut dengan equidispersi [17].

\section{G. Regresi Binomial Negatif}

Regresi binomial negatif merupakan salah salah satu solusi untuk mengatasi adanya kasus overdispersi. Model regresi binomial negatif memiliki fungsi massa peluang seperti persamaan dibawah ini [18].

$$
f(y, \mu, \theta)=\frac{\Gamma\left(y+\theta^{-1}\right)}{\Gamma\left(\theta^{-1}\right) \Gamma(y+1)}\left(\frac{1}{1+\theta \mu}\right)^{\theta^{-1}}\left(\frac{\theta \mu}{1+\theta \mu}\right)^{y}
$$

Model binomial negatif merupakan paduan antara distibusi Poisson dan Gamma. Berikut ini merupakan model regresi binomial negatif.

$$
\mu_{i}=\exp \left(\beta_{0}\left(u_{i}, v_{i}\right)+\beta_{1}\left(u_{i}, v_{i}\right) x_{i 1}+\ldots+\beta_{p}\left(u_{i}, v_{i}\right) x_{i p}\right)
$$

Pendugaan parameter model regresi binomial negatif menggunakan metode Maximum Likelihood Estimation (MLE). Kemudian untuk mendapatkan nilai dari parameternya digunakan iterasi Newton Raphson.

\section{H. Pengujian Aspek Spasial}

Pengujian aspek spasial bertujuan untuk melihat apakah data pada penelitian layak untuk dianalisis menggunakan regresi spasial atau tidak. Pada pengujian ini akan dilakukan uji heterogenitas spasial. Perbedaan karakteristik antar satu titik pengamatan dengan titik pengamatan yang lain menyebabkan adanya heterogenitas spasial. Untuk melihat adanya heterogenitas spasial pada data dapat dilakukan pengujian Breusch-Pagan [19]. Hipotesis pengujian tersebut adalah sebagai berikut:

$$
\begin{aligned}
& \mathrm{H}_{0}: \alpha_{1}^{2}=\alpha_{2}^{2}=\cdots=\alpha_{n}{ }^{2}=\alpha^{2} \\
& \mathrm{H}_{1}: \text { paling sedikit ada satu } \alpha_{i}^{2} \neq \alpha^{2} ; \quad \mathrm{i}=1,2, \cdots, n .
\end{aligned}
$$

Statistik uji :

$$
B P=\left(\frac{1}{2}\right) \mathbf{f}^{\mathrm{T}} \mathbf{Z}\left(\mathbf{Z}^{\mathrm{T}} \mathbf{Z}\right)^{-1} \mathbf{Z}^{\mathrm{T}} \mathbf{f}^{\sim} \chi_{(p)}^{2}
$$

Daerah penolakan : Tolak $\mathrm{H}_{0}$ jika nilai $B P>\chi_{(\alpha ; p)}^{2}$ yang mempunyai arti bahwa variasi antar lokasi berbeda.

I. Geographically Weighted Negative Binomial Regression (GWNBR)

Model GWNBR akan menghasilkan parameter local dengan masing-masing lokasi akan mempunyai parameter yang berbeda-beda. Bentuk umum dari model GWNBR dapat dilihat dibawah ini [8].

$$
y_{i} \sim N B\left\lfloor t_{j} \exp \left(\sum_{p} \beta_{p}\left(u_{i}, v_{i}\right) x_{i p}\right), \theta\left(u_{i}, v_{i}\right)\right\rfloor ; i=1,2, \ldots, n
$$

1. Estimasi Parameter

Estimasi parameter model GWNBR menggunakan metode Maksimum Likelihood. Fungsi likelihood dapat dituliskan seperti dibawah ini [8].

$L\left(\beta\left(u_{i}, v_{i}\right), \theta_{i} \mid y_{i}, x_{i}\right)=\prod_{i=1}^{n}\left(\prod_{r=0}^{p-1}\left(r+\frac{1}{\theta_{i}}\right)\right) \frac{1}{y !}\left(\frac{1}{1+\theta \mu}\right)^{\frac{1}{\theta}}\left(\frac{\theta \mu}{1+\theta \mu}\right)^{y}$

Estimasi GWNBR juga menggunakan metode yang sama dengan regresi Poisson, yaitu dengan cara metode Newton Raphson. Langkah-langkah dalam penggunaan metode Newton Raphson, dapat dilihat pada estimasi parameter pada regresi Poisson.

2. Pengujian Secara Serentak

Pengujian signifikan parameter model GWNBR terdiri dari uji serentak dan parsial. Uji signifikansi secara serentak dengan menggunakan Maximum Likelihood Ratio Test (MLRT) dengan hipotesis sebagai berikut:

$\mathrm{H}_{0}: \beta_{1}\left(u_{i}, v_{i}\right)=\beta_{2}\left(u_{i}, v_{i}\right)=\ldots=\beta_{p}\left(u_{i}, v_{i}\right)=0$ 
$\mathrm{H}_{1}$ : paling sedikit ada satu $\beta_{k}\left(u_{i}, v_{i}\right) \neq 0 \quad k=1,2, \cdots, p$. Statistik uji:

$$
G^{2}=-2 \ln \left(\frac{L(\hat{\omega})}{L(\hat{\Omega})}\right)=2(\ln L(\hat{\omega})-\ln L(\hat{\Omega}))
$$

Daerah penolakan : Tolak $\mathrm{H}_{0}$ jika $|G|>\chi_{(\alpha, p)}^{2}$.

3. Pengujian Secara Parsial

Pengujian signifikansi secara parsial dilakukan untuk mengetahui parameter mana saja yang memberikan pengaruh yang signifikan terhadap variabel respon pada tiap- tiap lokasi dengan hipotesis sebagai berikut:

$$
\begin{aligned}
& \mathrm{H}_{0}: \beta_{k}\left(u_{i}, v_{i}\right)=0 \\
& \mathrm{H}_{1}: \beta_{k}\left(u_{i}, v_{i}\right) \neq 0 ; k=1,2, \ldots, p .
\end{aligned}
$$

Statistik uji :

$$
Z=\frac{\widehat{\beta}_{k}\left(u_{i}, v_{i}\right)}{\operatorname{SE}\left(\widehat{\beta}_{k}\left(u_{i}, v_{i}\right)\right)}
$$

Daerah penolakan : Tolak $\mathrm{H}_{0}$ jika $|Z|>Z_{\alpha / 2}$. Tolak $\mathrm{H} 0$ artinya bahwa parameter tersebut berpengaruh signifikan terhadap variabel respon di tiap lokasi [8].

\section{J. Geographically Weighted Poisson Regression (GWPR)}

Geographically Weighted Poisson Regression adalah metode yang cukup efektif dalam menduga data yang memiliki heterogenitas spasial (karakteristik yang berbeda antar wilayah) untuk data count. Model GWPR merupakan metode hasil pengembangan dari model regresi Poisson. Model GWPR akan menghasilkan parameter lokal yang masing-masing lokasi memiliki parameter yang berbeda-beda [7]. Persamaan pada model GWPR dapat dirumuskan seperti dibawah ini.

$$
\begin{gathered}
P\left[\exp \left(\sum_{k=0}^{p} \beta_{k}\left(u_{i}, v_{i}\right) x_{i j}\right)\right]{ }_{i=1,2,3, \ldots, n} \\
E\left(y_{i}\right)=\mu\left(\mathbf{x}_{i}, \boldsymbol{\beta}\left(u_{i}, v_{i}\right)\right)=\exp \left(\mathbf{x}_{i}^{T} \boldsymbol{\beta}\left(u_{i}, v_{i}\right)\right) ; i=1,2, \ldots, n
\end{gathered}
$$

Estimasi parameter model GWPR diperoleh melalui iteraksi numerik yaitu iteraksi Newton-Raphson untuk menemukan solusi dari fungsi ln-likelihood sehingga diperoleh nilai yang konvergen. bentuk In-likelihood untuk model Geographically Weighted Poisson Regression dapat dilihat dibawah ini.

$$
\ln L^{*}\left(\boldsymbol{\beta}\left(u_{i}, v_{i}\right)\right)=\sum_{i=1}^{n}\left(y_{i} \mathbf{x}_{i}^{T} \boldsymbol{\beta}\left(u_{i}, v_{i}\right)-\exp \left(\mathbf{x}_{i}^{T} \boldsymbol{\beta}\left(u_{i}, v_{i}\right)\right)-\ln y_{i} !\right) w_{i j}\left(u_{i}, v_{i}\right)
$$

Penaksiran parameter diperoleh dengan menurunkan persamaan diatas terhadap $\boldsymbol{\beta}^{T}\left(u_{i}, v_{i}\right)$ kemudian hasilnya disamakan dengan nol sehingga diperoleh persamaan 17.

$$
\frac{\partial \ln L^{*}\left(\boldsymbol{\beta}\left(u_{i}, v_{i}\right)\right)}{\partial \boldsymbol{\beta}^{T}\left(u_{i}, v_{i}\right)}=\sum_{i=1}^{n}\left(y_{i} \mathbf{x}_{i}-\mathbf{x}_{i} \exp \left(\mathbf{x}_{i}^{T} \boldsymbol{\beta}\left(u_{i}, v_{i}\right)\right)\right) w_{i j}\left(u_{i}, v_{i}\right)=0
$$

Oleh karena persamaan yang dihasilkan adalah persamaan yang berbentuk implisit maka salah satu alternatif penyelesaiannya digunakan suatu prosedur iterasi numerik yaitu metode Newton-RaphsonIteratively Rewighted Least Square (IRLS). Secara umum, persamaan untuk metode Newton-RaphsonIteratively Rewighted Least Square dapat dilihat pada persamaan 18 .

$$
\boldsymbol{\beta}_{(m+1)}\left(u_{i}, v_{i}\right)=\boldsymbol{\beta}_{(m)}\left(u_{i}, v_{i}\right)-\mathbf{H}_{(m)}^{-1}\left(\boldsymbol{\beta}_{(m)}\left(u_{i}, v_{i}\right)\right) \mathbf{g}_{(m)}\left(\boldsymbol{\beta}_{(m)}\left(u_{i}, v_{i}\right)\right)
$$

Faktor geografis merupakan faktor pembobot pada model GWPR. Faktor ini memiliki nilai yang berbeda untuk setiap wilayah pada model GWPR [17]. Terdapat beberapa fungsi pembobot yang sering digunakan yaitu Fungsi Fixed Bisquare Kernel dan Fungsi Fixed Gaussian Kernel yang persamaannya bisa dilihat dibawah ini.

Fungsi Fixed Bisquare Kernel

$$
w_{i j\left(u_{i}, v_{i}\right)}=\left\{\begin{array}{cr}
\left(1-\left(\frac{d_{i j}}{h}\right)^{2}\right)^{2} & \text { untuk } d_{i j} \leq h_{i} \\
0 & \text { untuk } d_{i j}>h_{i}
\end{array}\right.
$$

Fungsi Fixed Gaussian Kernel

$$
w_{i j\left(u_{i}, v_{i}\right)}=\exp \left[-\left(\frac{d_{i j}}{h}\right)^{2}\right]
$$

1. Pengujian secara serentak

Pengujian signifikansi parameter model GWPR secara senrentak dengan menggunakan Maximum Likelihood Ratio Test (MLRT) dengan hipotesis sebagai berikut:

$$
\begin{aligned}
& \mathrm{H}_{0}: \beta_{1}\left(u_{i}, v_{i}\right)=\beta_{2}\left(u_{i}, v_{i}\right)=\cdots=\beta_{p}\left(u_{i}, v_{i}\right)=0 \\
& \mathrm{H}_{1}: \beta_{k}\left(u_{i}, v_{i}\right) \neq 0 ; i=1,2, \cdots, n ; k=0,1,2, \cdots, p .
\end{aligned}
$$

Statistik uji :

$$
D(\widehat{\beta})=-2 \ln \left(\frac{L(\widehat{\omega})}{L(\widehat{\Omega})}\right)=2(\ln L(\widehat{\Omega})-\ln L(\widehat{\omega})
$$

Daerah penolakan : Tolak $\mathrm{H}_{0}$ jika statistik uji nilai $D(\widehat{\beta})>\chi^{2}(p ; \alpha)$.

2. Pengujian secara parsial

Pengujian parameter secara parsial digunakan untuk mengetahui parameter mana saja yang memberikan pengaruh yang signifikan terhadap variabel respon pada tiap-tiap lokasi dengan hipotesis seperti dibawah ini.

$$
\begin{aligned}
& \mathrm{H}_{0}: \beta_{k}\left(u_{i}, v_{i}\right)=0 \\
& \mathrm{H}_{1}: \beta_{k}\left(u_{i}, v_{i}\right) \neq 0
\end{aligned}
$$

Statistik uji :

$$
Z=\frac{\widehat{\beta}_{k}\left(u_{i}, v_{i}\right)}{\operatorname{se}\left(\widehat{\beta}_{k}\left(u_{i}, v_{i}\right)\right)}
$$

Daerah penolakan : Tolak $\mathrm{H}_{0}$ jika $|Z|>Z_{\alpha / 2}$.

\section{METODOLOGI PENELITIAN}

\section{A. Sumber Data}

Data yang digunakan dalam penelitian ini adalah data sekunder. Variabel respon yaitu property crime diambil dari data kepolisian masing-masing provinsi di Provinsi Jawa Timur. Sedangkan data dari faktor-faktor yang mempengaruhi property crime diperoleh melalui publikasi data profil daerah, Badan Pusat Statistik (BPS), dan data Kepolisian Daerah Jawa Timur Bagian Direskrimum. Penelitian ini menggunakan masing-masing data dari 38 kabupaten/kota di Provinsi Jawa Timur yang diambil pada tahun 2017 [20].

\section{B. Variabel Penelitian}

Adapun variabel respon yang digunakan dalam penelitian ini adalah jumlah kasus property crime yang ada di 
Provinsi Jawa Timur. Sedangkan pada setiap variabel prediktor juga akan diteliti per provinsi yang ada di Provinsi Jawa Timur. Berikut merupakan variabel yang digunakan dalam penelitian ini yang teringkas dalam Tabel 1 .

Tabel 1. Variabel Penelitian

\begin{tabular}{|c|c|c|}
\hline Var & Keterangan & Dasar Pengambilan Variabel \\
\hline Y & Property Crime & Penelitian Becker tahun 1993 \\
\hline $\mathrm{X}_{1}$ & $\begin{array}{l}\text { Kepadatan } \\
\text { Penduduk }\end{array}$ & Penelitian Nassarudin tahun 2016 \\
\hline $\mathrm{X}_{2}$ & $\begin{array}{l}\text { Banyak Rumah } \\
\text { Tangga }\end{array}$ & Penelitian Nassarudin tahun 2016 \\
\hline $\mathrm{X}_{3}$ & $\begin{array}{c}\text { Banyak Anggota } \\
\text { RT }\end{array}$ & $\begin{array}{c}\text { Penelitian Soekanto \& Soerjono } \\
\text { tahun } 2001\end{array}$ \\
\hline $\mathrm{X}_{4}$ & $\begin{array}{l}\text { Angka Partisipasi } \\
\text { Sekolah }>15 \mathrm{Th}\end{array}$ & Penelitian Lochner tahun 1999 \\
\hline $\mathrm{X}_{5}$ & $\begin{array}{l}\text { Angkatan Kerja } \\
>15 \mathrm{Thn}\end{array}$ & Penelitian Lochner tahun 1999 \\
\hline $\mathrm{X}_{6}$ & IPM & Penelitian Lochner tahun 1999 \\
\hline $\mathrm{X}_{7}$ & Rasio Gini & Penelitian Becker tahun 1993 \\
\hline $\mathrm{X}_{8}$ & Dependency Ratio & Penelitian Becker tahun 1993 \\
\hline $\mathrm{X}_{9}$ & UMR-KHL & Penelitian Becker tahun 1993 \\
\hline $\mathrm{X}_{10}$ & PDRB & Penelitian Becker tahun 1993 \\
\hline $\mathrm{X}_{11}$ & Kemiskinan & Penelitian Nassarudin tahun 2016 \\
\hline $\mathrm{X}_{12}$ & $\begin{array}{l}\text { Pengeluaran Per } \\
\text { Kapita }\end{array}$ & Penelitian Becker tahun 1993 \\
\hline $\mathrm{X}_{13}$ & $\begin{array}{l}\text { Pendapatan Bersih } \\
\text { Pekerja Bebas }\end{array}$ & Penelitian Becker tahun 1993 \\
\hline $\mathrm{X}_{14}$ & $\begin{array}{l}\text { Kebutuhan Hidup } \\
\text { Minimum }\end{array}$ & Penelitian Becker tahun 1993 \\
\hline
\end{tabular}

C. Langkah Analisis

Langkah-langkah analisis yang digunakan untuk menjawab tujuan dari penelitian ini antara lain sebagai berikut:

1. Mendeskripsikan karakteristik jumlah property crime di Provinsi Jawa Timur menggunakan analisis statistika deskriptif dan pemetaan wilayah dengan peta tematik untuk masing-masing variabel.

2. Mengidentifikasi dan menangani masalah multikolinieritas dengan melihat kriteria korelasi dan VIF.

3. Menganalisis model regresi Poisson dengan langkah berikut:

a. Penaksiran parameter model regresi Poisson menggunakan metode MLE.

b. Menguji signifikansi parameter model regresi Poisson secara serentak dan parsial.

c. Menghitung nilai AIC model regresi Poisson.

4. Mengidentifikasi overdispersi pada regresi Poisson.

5. Menganalisis model regresi Binomial negatif dengan langkah berikut:

a. Penaksiran parameter model regresi Binomial negatif menggunakan metode MLE.

b. Menguji signifikansi parameter model regresi Binomial negatif secara serentak dan parsial. c. Menghitung nilai AIC model regresi Binomial negatif.

6. Melakukan pengujian aspek data spasial. Uji BreuschPagan untuk melihat heterogenitas spasial data dan uji Moran I untuk menguji dependensi spasial data.

7. Memodelkan GWNBR dengan langkah-langkah sebagai berikut:

a. Menghitung jarak Euclidean antar lokasi pengamatan berdasarkan posisi geografis.

b. Mendapatkan bandwidth optimal untuk setiap lokasi pengamatan dengan menggunakan Cross Validation (CV).

c. Menghitung matrik pembobot dengan menggunakan fungsi kernel fix Gaussian.

d. Melakukan pengujian kesamaan model GWNBR dengan regresi Binomial Negatif dan pengujian signifikansi parameter model secara serentak maupun parsial.

e. Melakukan intepretasi model GWNBR yang didapatkan dan membentuk peta pengelompokkan.

f. Menghitung nilai AIC pada model GWNBR

8. Memodelkan GWPR dengan langkah-langkah sebagai berikut:

a. Menghitung jarak Euclidean antar lokasi pengamatan berdasarkan posisi geografis.

b. Mendapatkan bandwidth optimal untuk setiap lokasi pengamatan dengan menggunakan Cross Validation (CV).

c. Menghitung matrik pembobot dengan menggunakan fungsi kernel fix Gaussian.

d. Melakukan pengujian kesamaan model GWPR dengan regresi Binomial Negatif dan pengujian signifikansi parameter model secara serentak maupun parsial.

e. Melakukan intepretasi model GWPR yang didapatkan dan membentuk peta pengelompokkan.

f. Menghitung nilai AIC pada model GWPR

9. Membandingkan nilai AIC diantara model Regresi Poisson, Regresi Binomial Negatif, GWNBR, dan GWPR.

10. Menarik Kesimpulan dan Saran.

\section{ANALISIS DAN PEMBAHASAN}

Pada bab ini membahas hasil dari analisis untuk menjawab rumusan masalah dalam penelitian

A. Karakteristik Jumlah Kasus Property Crime Tahun 2017 di Provinsi Jawa Timur

Jumlah kasus property crime di Jawa Timur menempati peringkat kedua tertinggi di Indonesia setelah Jawa Timur. Berikut ini terdapat gambaran awal tentang jumlah kasus property crime di Jawa Timur dengan menggunakan peta tematik. Metode yang digunakan dalam pembuatan peta 
tematik adalah metode Natural Breaks yang terbagi dalam 5 kelompok yaitu sangat rendah, rendah, sedang, tinggi, dan sangat tinggi. Metode Natural Breaks digunakan karena tidak meratanya data jumlah kasus property crime di setiap kabupaten/kota. Persebaran jumlah kasus property crime di Jawa Timur pada tahun 2017 disajikan dalam Gambar 1 berikut ini.

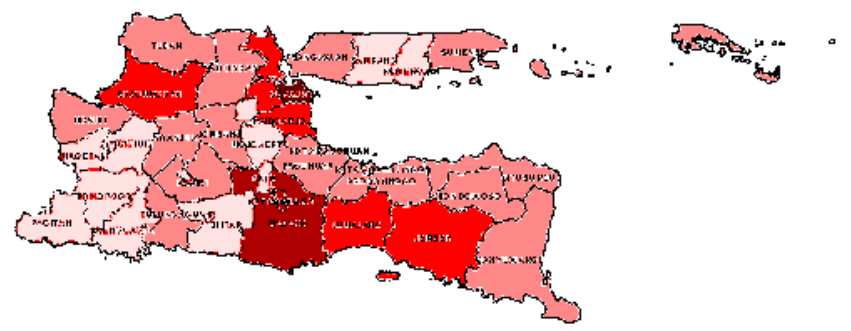

Gambar 1. Persebaran Jumlah Kasus Property Crime di Jawa Timur Tahun 2017

Berdasarkan Gambar 1 dapat diketahui bahwa daerah yang memiliki jumlah kasus properti crime sangat rendah sebanyak 14 kabupaten/kota yang digambarkan dengan warna putih. Pada kelompok sedang terdapat 5 kabupaten/kota digambarkan dengan warna kemerahan. Sedangkan kelompok sangat tinggi yaitu Kota Surabaya yang digambarkan dengan warna merah tua gelap. Pada tahun 2017 jumlah kasus properti crime di Jawa Timur mencapai 7815 kasus dengan rata-rata sebanyak 206 kasus per kabupaten/kota. Kota Surabaya memiliki jumlah kasus properti crime paling banyak dengan jumlah 1466 kasus. Sedangkan Kabupaten Pacitan memiliki jumlah kasus properti crime paling sedikit yaitu 33 kasus. Jumlah kasus properti crime memiliki standar deviasi yang besar yaitu 270,579 karena terdapat perbedaan yang signifikan antara jumlah kasus properti crime masing-masing kabupaten/kota di Jawa Timur.

\section{B. Pemeriksaan Multikolinieritas}

Sebelum melakukan analisis menggunakan metode Regresi Poisson, Geographically Weighted Negative Binomial Regression (GWNBR), dan Geographically Weighted Poisson Regression (GWPR) maka perlu dilakukan pengujian multikolinieritas terhadap data yang digunakan untuk mengetahui ada atau tidaknya diantara variabel prediktor memiliki korelasi yang cukup tinggi. Cara untuk mendeteksi adanya kasus multikolinieritas, yaitu dengan melihat nilai VIF (Variance Inflation Factor). Untuk mendapatkan nilai VIF dengan cara meregresikan masingmasing variabel prediktor dengan semua variabel prediktor lainnya, sehingga diperoleh nilai $R^{2}$ untuk setiap variabel prediktor yang diregresikan. Lalu untuk mencari nilai VIF dengan melakukan invers terhadap nilai $R^{2}$ tersebut. Berikut ini merupakan nilai VIF pada setiap variabel prediktor.

Multikolineritas terjadil apabila nilai VIF pada setiap variabel prediktor mempunyai nilai lebih dari 5. Berdasarkan Tabel 4.1 diatas, variabel $\mathrm{X}_{1}, \mathrm{X}_{2}, \mathrm{X}_{5}, \mathrm{X}_{6}, \mathrm{X}_{10}, \mathrm{X}_{11}, \mathrm{X}_{12}$, dan $\mathrm{X}_{14}$ mempunyai nilai VIF lebih dari 5. Artinya bahwa pada variabel tersebut terjadi multikolinieritas. Sehingga perlu penanganan pada variabel tersebut agar bisa dilakukan analisis berikutnya.
Tabel 2. Nilai VIF Setiap Variabel Prediktor

\begin{tabular}{lr}
\hline \hline Variabel & \multicolumn{1}{c}{ VIF } \\
\hline $\mathbf{X}_{\mathbf{1}}$ & 8,444 \\
$\mathbf{X}_{\mathbf{2}}$ & 264,058 \\
$\mathbf{X}_{\mathbf{3}}$ & 4,114 \\
$\mathbf{X}_{\mathbf{4}}$ & 4,244 \\
$\mathbf{X}_{\mathbf{5}}$ & 300,026 \\
$\mathbf{X}_{\mathbf{6}}$ & 16,026 \\
$\mathbf{X}_{\mathbf{7}}$ & 3,488 \\
$\mathbf{X}_{\mathbf{8}}$ & 3,712 \\
$\mathbf{X}_{\mathbf{9}}$ & 3,924 \\
$\mathbf{X}_{\mathbf{1 0}}$ & 6,013 \\
$\mathbf{X}_{\mathbf{1 1}}$ & 12,488 \\
$\mathbf{X}_{\mathbf{1 2}}$ & 21,745 \\
$\mathbf{X}_{\mathbf{1 3}}$ & 4,054 \\
$\mathbf{X}_{\mathbf{1 4}}$ & 6,801 \\
\hline \hline
\end{tabular}

Selanjutnya penanganan variabel yang terjadi kasus multikolinieritas dengan menggunakan metode seleksi Forward. Berikut merupakan hasil step ke-6 seleksi Forward yang bisa dilihat pada Tabel 3 .

Tabel 3. Hasil Step ke-6 Metode Seleksi Forward

\begin{tabular}{crr}
\hline \hline Parameter & Estimasi & P-Value \\
\hline $\mathrm{X}_{10}$ & 0,00106 & 0,043 \\
$\mathrm{X}_{12}$ & 0,00072 & 0 \\
$\mathrm{X}_{2}$ & 0,00071 & 0,001 \\
$\mathrm{X}_{9}$ & $-0,00015$ & 0,012 \\
$\mathrm{X}_{4}$ & $-6,5$ & 0,017 \\
$\mathrm{X}_{13}$ & $-0,0002$ & 0,043 \\
\hline \hline
\end{tabular}

Hasil pada Tabel 3 merupakan model terbaik yang diperoleh dengan menggunakan metode seleksi Forward. Nilai $\mathrm{R}^{2}$ yang dihasilkan dari model tersebut sebesar $82,83 \%$. Artinya bahwa model yang dihasilkan dapat menjelaskan variabel respon sebesar $82,83 \%$. Setelah itu akan dilakukan kembali pemeriksaan multikolinieritas dengan melihat nilai VIF yang dihasilkan oleh variabel tersebut. Hasil pemeriksaan VIF disajikan dalam Tabel 4.

Berdasarkan pemeriksaan multikolinieritas diketahui bahwa keseluruhan variabel memiliki nilai VIF kurang dari 5 sehingga dapat disimpulkan bahwa data tersebut tidak terdapat kasus multikolinieritas. Sehingga dapat diputuskan bahwa variabel banyak rumah tangga $\left(\mathrm{X}_{2}\right)$, angka partisipasi sekolah $\left(\mathrm{X}_{4}\right)$, UMR-KHL $\left(\mathrm{X}_{9}\right)$, PDRB $\left(\mathrm{X}_{10}\right)$, pengeluaran per kapita $\left(\mathrm{X}_{12}\right)$, dan pendapatan bersih pekerja bebas $\left(\mathrm{X}_{13}\right)$ akan digunakan dalam model. 
Tabel 4. Nilai VIF Setiap Variabel Prediktor yang Telah Bebas

\begin{tabular}{cc}
\multicolumn{2}{c}{ Multikolinieritas } \\
\hline \hline Variabel & VIF \\
\hline $\mathbf{X}_{\mathbf{2}}$ & 3,058 \\
$\mathbf{X}_{\mathbf{4}}$ & 1,702 \\
$\mathbf{X}_{\mathbf{9}}$ & 2,353 \\
$\mathbf{X}_{\mathbf{1 0}}$ & 4,217 \\
$\mathbf{X}_{\mathbf{1 2}}$ & 3,736 \\
$\mathbf{X}_{\mathbf{1 3}}$ & 1,647 \\
\hline
\end{tabular}

\section{Pemodelan Regresi Poisson}

Regresi Poisson merupakan model regresi non-linier yang digunakan untuk jenis data count dimana variabel respon mengikuti distribusi Poisson. Setelah dilakukan pemeriksaan kasus multikolinieritas antara variabel prediktor dan diperoleh hasil bahwa variabel yang digunakan sebanyak 6 variabel prediktor antara lain $\mathrm{X}_{2}, \mathrm{X}_{4}, \mathrm{X}_{9}, \mathrm{X}_{10}, \mathrm{X}_{12}$, dan $\mathrm{X}_{13}$. Kemudian melakukan pemodelan regresi Poisson dengan variabel tersebut. Berikut merupakan model regresi poisson terhadap data property crime di Jawa Timur.

$$
\begin{aligned}
\ln (\widehat{\mu}) & =4,535+0,0000034 X_{2}-0,01976 X_{4}-0,0000001 X_{9} \\
& -0,0000028 X_{10}+0,0000027 X_{12}-0,0000009 X_{13}
\end{aligned}
$$

Selanjutnya dilakukan uji serentak dan parsial untuk melihat variabel yang signifikan terhadap model.

a. Uji Serentak

Pengujian signifikasi model regresi Poisson secara serentak bertujuan untuk mengetahui apakah secara serentak variabel prediktor memberikan pengaruh terhadap model. Berdasarkan hasil pengujian dengan menggunakan software $\mathrm{R}$ diperoleh nilai devians model regresi poisson sebesar 1046,3. Dengan taraf signifikansi $25 \%$ didapatkan nilai tabel sehingga diputuskan Tolak $\mathrm{H}_{0}$ yang artinya paling tidak ada salah satu variabel prediktor yang berpengaruh signifikan terhadap variabel respon.

\section{b. Uji Parsial}

Pengujian parameter secara parsial digunakan untuk mengetahui parameter mana saja yang memberikan pengaruh yang signifikan terhadap variabel respon pada tiap-tiap lokasi. Berdasarkan hasil output software $R$, diketahui bahwa semua variabel memiliki nilai P-value kurang dari $\alpha$ sebesar 25\% maka diputuskan Tolak $\mathrm{H}_{0}$. Artinya semua variabel memberikan pengaruh terhadap model. Sehingga semua variabel berpengaruh signifikan terhadap jumlah property crime di Jawa Timur.

\section{Overdispersi}

Regresi Poisson mempunyai ciri yaitu nilai rata-rata sama dengan nilai varian yang biasa disebut equidispersion. Equidispersi dapat dilihat dengan koefisien dispersi yang memiliki nilai 1. Pada kasus jumlah kasus property crime akan diperiksa ada atau tidaknya kasus overdispersi yang ditunjukkan oleh besarnya koefisien dispersi lebih dari 1 . Untuk mendeteksi keberadaan overdispersion adalah nilai deviance pada model regresi Poisson dibagi dengan derajat bebasnya. Nilai deviance model regresi Poisson sebesar 1046,3 dengan derajat bebas 31 sehingga rasio nilai devians dengan derajat bebasnya bernilai 33.752. Nilai tersebut lebih besar dari angka 1 yang artinya data jumlah kasus property crime mengalami kasus overdispersion. Sehingga regresi Poisson tidak sesuai untuk kasus overdispersi karena akan menghasilkan estimasi parameter yang bias dan tidak efisien.

Distribusi yang sering digunakan untuk kasus overdispersion adalah binomial negatif. Langkah awal dalam melakukan pemodelan regresi binomial negatif adalah menentukan nilai initial $\theta$ yang bertujuan untuk meminimumkan parameter disperse, sehingga dapat mengatasi kasus overdispersi. Initial $\theta$ didapatkan melalui hasil trial error sampai mendapatkan rasio nilai devians dengan derajat bebasnya bernilai 1 yang artinya tidak terdapat kasus overdispersi. Untuk menentukan nilai awal dalam trial error, menggunakan nilai $\theta$ yang diperoleh dari hasil regresi binomial negatif. Berikut ini merupakan hasil trial error initial $\theta$ yang disajikan dalam Tabel 5.

Tabel 5. Hasil Trial Error Initial $\theta$

\begin{tabular}{cccc}
\hline \hline Initial $\boldsymbol{\theta}$ & Deviance & df & Deviance $/ \mathbf{d f}$ \\
\hline $\mathbf{8 , 5}$ & 53,585 & 31 & 1,728548387 \\
$\mathbf{5}$ & 32,373 & 31 & 1,044290323 \\
$\mathbf{4 , 8}$ & 31,126 & 31 & 1,004064516 \\
$\mathbf{4 , 7 8}$ & 31,002 & 31 & 1,000064516 \\
$\mathbf{4 , 7 7 9 8}$ & 31 & 31 & 1 \\
\hline \hline
\end{tabular}

Berdasarkan hasil trial error initial $\theta$ didapatkan initial $\theta$ yang memiliki rasio nilai devians dengan derajat bebasnya yaitu bernilai 1 adalah sebesar 4,7798. Sehingga dilakukan pemodelan regresi binomial negatif dengan initial $\theta$ sebesar 4,7798 .

\section{E. Pemodelan Regresi Binomial Negatif}

Regresi binomial negatif dapat juga digunakan untuk mengatasi kasus overdispersi yang terjadi pada regresi poisson. Setelah dilakukan pemeriksaan kasus multikolinieritas antara variabel prediktor dan diperoleh hasil bahwa variabel yang digunakan sebanyak 6 variabel prediktor antara lain $\mathrm{X}_{2}, \mathrm{X}_{4}, \mathrm{X}_{9}, \mathrm{X}_{10}, \mathrm{X}_{12}$, dan $\mathrm{X}_{13}$. Kemudian melakukan pemodelan regresi binomial negatif dengan variabel tersebut dan dengan nilai $\theta$ sebesar 4,7798. Berikut merupakan model regresi binomial negatif terhadap data property crime di Jawa Timur.

$$
\begin{aligned}
\ln (\hat{\mu}) & =4,578+0,0000034 X_{2}-0,01941 X_{4}-0,0000001 X_{9} \\
& -0,0000017 X_{10}+0,0000021 X_{12}-0,0000005 X_{13}
\end{aligned}
$$

Selanjutnya dilakukan uji serentak dan parsial untuk melihat variabel yang signifikan terhadap model.

a. Uji Serentak

Pengujian signifikasi model regresi binomial negatif secara serentak bertujuan untuk mengetahui apakah secara serentak variabel prediktor memberikan pengaruh terhadap model. Berdasarkan hasil pengujian dengan menggunakan software $\mathrm{R}$ diperoleh nilai devians model regresi binomial negatif sebesar 31. Dengan taraf signifikansi $25 \%$ didapatkan nilai tabel sehingga 
diputuskan Tolak $\mathrm{H}_{0}$ yang artinya paling tidak ada salah satu variabel prediktor yang berpengaruh signifikan terhadap variabel respon.

b. Uji Parsial

Pengujian parameter secara parsial digunakan untuk mengetahui parameter mana saja yang memberikan pengaruh yang signifikan terhadap variabel respon pada tiap-tiap lokasi. Berdasarkan hasil output dari software $R$, diketahui bahwa variabel UMR-KHL $\left(\mathrm{X}_{9}\right)$ dan PDRB $\left(\mathrm{X}_{10}\right)$ memiliki nilai $\mathrm{P}$-value lebih dari $\alpha$ sebesar $25 \%$ maka diputuskan Gagal Tolak H0, yang artinya variabel UMR-KHL $\left(\mathrm{X}_{9}\right)$ dan PDRB $\left(\mathrm{X}_{10}\right)$ tidak memberikan pengaruh terhadap model. Sedangkan untuk variabel selain UMR-KHL $\left(\mathrm{X}_{9}\right)$ dan PDRB $\left(\mathrm{X}_{10}\right)$ berpengaruh signifikan terhadap jumlah property crime di Jawa Timur.

\section{F. Pengujian Aspek Spasial}

Pengujian aspek spasial merupakan pengujian untuk melihat apakah data penelitian layak untuk dianalisis menggunakan regresi spasial. Pengujian heterogentias spasial dapat dilakukan dengan uji Breusch-Pagan dengan hipotesis sebagai berikut:

$\mathrm{H}_{0}: \alpha_{1}{ }^{2}=\alpha_{2}{ }^{2}=\cdots=\alpha_{38}{ }^{2}=\alpha^{2}$ (varian antar lokasi sama)

$\mathrm{H}_{1}$ : paling sedikit ada satu $\alpha_{i}^{2} \neq \alpha^{2} ; \quad i=1,2, \cdots, 33$.

Berdasarkan hasil pengujian diperoleh nilai BP test sebesar 14,321 dan p-value sebesar 0,02625. Jika nilai BP test dibandingkan dengan nilai maka diketahui bahwa nilai BP test lebih besar dari 3,454599 sehingga diputuskan tolak $\mathrm{H}_{0}$. Artinya bahwa variansi antarlokasi tidak sama atau terdapat perbedaan karakteristik antara satu titik pengamatan dengan titik pengamatan lainnya.

Berdasarkan pengujian aspek spasial yaitu pengujian heterogenitas spasial diketahui bahwa data jumlah property crime di Jawa Timur memenuhi aspek spasial, sehingga dapat dilanjutkan pemodelan dengan menggunakan metode GWNBR dan GWPR.

G. Pemodelan Geographically Weighted Negatif Binomial Regression (GWNBR)

Geographically Weighted Negative Binomial Regression (GWNBR) merupakan pengembangan dari regresi binomial negatif. Model GWNBR menggunakan pembobot geografis pada penaksiran parameternya. Matriks pembobot didapatkan dengan menggunakan pembobot fungsi Kernel fix Gaussian. Sehingga akan diperoleh parameter yang berbeda-beda untuk setiap kabupaten/kota di Jawa Timur.

a. Pengujian Serentak

Pengujian signifikasi model GWNBR secara serentak bertujuan untuk mengetahui apakah secara serentak variabel prediktor memberikan pengaruh terhadap model

Berdasarkan hasil pengujian dengan menggunakan software $\mathrm{R}$ diperoleh nilai devians model GWNBR sebesar 31,24769. Dengan taraf signifikansi 25\% didapatkan nilai tabel sehingga diputuskan Tolak $\mathrm{H} 0$ yang artinya paling tidak ada salah satu variabel prediktor yang berpengaruh signifikan terhadap variabel respon.

b. Pengujian Parsial

Pengujian parameter secara parsial digunakan untuk mengetahui parameter mana saja yang memberikan pengaruh yang signifikan terhadap variabel respon pada tiap-tiap lokasi.

Berdasarkan hasil pengujian parsial GWNBR diketahui bahwa nilai parameter yang signifikan berbedabeda setiap wilayah. Hasil estimasi dan nilai $Z_{\text {hit }}$ parameter GWNBR dapat dilihat pada tabel output. Nilai $Z_{\text {hit }}$ parameter setiap kabupaten/kota dibandingkan dengan $Z_{\text {tabel. }}$. Jika nilai $Z_{\text {hit }}>Z_{\text {tabel }}$ maka diputuskan Tolak $\mathrm{H} 0$, yang artinya variabel prediktor tersebut memberikan pengaruh terhadap model.

Hasil pengelompokan pertama menunjukkan bahwa variabel angka partisipasi sekolah $\left(\mathrm{X}_{4}\right)$ dan variabel pengeluaran per kapita $\left(\mathrm{X}_{12}\right)$ yang berpengaruh signifikan terhadap model untuk 25 kabupaten/kota di Jawa Timur. Sedangkan pada pengelompokan kedua hanya terdapat satu variabel yang signifikan terhadap model yaitu variabel angka partisipasi sekolah. Kelompok kedua berisikan 13 kabupaten/kota di Jawa Timur. Pengelompokan wilayah kabupaten/kota di Jawa Timur berdasarkan variabel yang signifikan disajikan dalam Gambar 2.

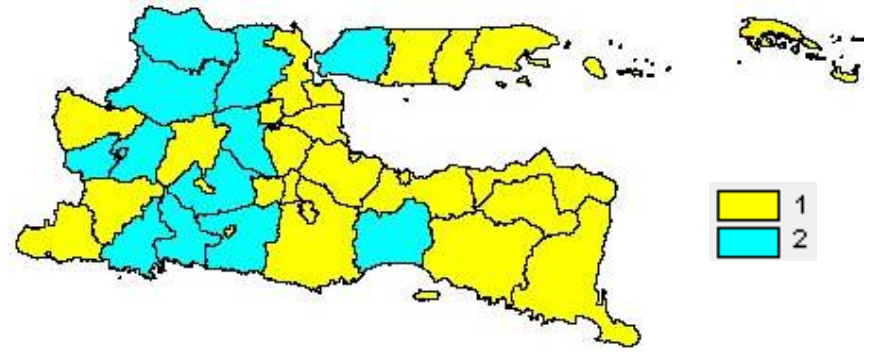

Gambar 2. Pengelompokan Berdasarkan Variabel yang Signifikan dengan Model GWNBR

c. Contoh Interpretasi Salah Satu Model Kabupaten/Kota di Jawa Timur

Interpretasi model GWNBR menggunakan lokasi ke$1\left(u_{1}, v_{1}\right)$ yaitu Kabupaten Pacitan dengan estimasi parameter. Disajikan juga pengujian parameter pada lokasi penelitian yang sama dengan contoh pemodelan metode GWNBR. Berikut merupakan pengujian parameter model GWNBR untuk Kabupaten Pacitan yang disajikan dalam Tabel 6 .

Karena nilai $\left|Z_{\text {hit }}\right|$ pada $\beta_{2}$ dan $\beta_{5}$ lebih besar dari $Z_{(\alpha / 2)}$ maka dapat disimpulkan bahwa variabel angka partisipasi sekolah $\left(\mathrm{X}_{4}\right)$ dan variabel pengeluaran per kapita $\left(\mathrm{X}_{12}\right)$ signifikan. Model regresi yang dapat dibentuk untuk Kabupaten Pacitan dapat dilhat pada persamaan dibawah ini.

$\ln (\widehat{\mu})=4,57751366-0,019411372 X_{2}+0,000002 X_{12}$ 
Tabel 6. Pengujian Parameter Model GWNBR di Kab. Pacitan

\begin{tabular}{cccr}
\hline \hline Parameter & Estimasi & $Z_{\text {hit }}$ & P-Value \\
\hline $\boldsymbol{\beta}_{\mathbf{0}}$ & 4,57751366 & $2,31 \mathrm{E}+11$ & 0 \\
$\boldsymbol{\beta}_{\mathbf{1}}$ & $3,25858 \mathrm{E}-06$ & 1,022223 & 0,236594 \\
$\boldsymbol{\beta}_{2}$ & $-0,019411372$ & $-1,6 \mathrm{E}+07$ & 0 \\
$\boldsymbol{\beta}_{3}$ & $-1,70789 \mathrm{E}-07$ & $-0,15005$ & 0,394476 \\
$\boldsymbol{\beta}_{4}$ & $-1,49135 \mathrm{E}-06$ & $-0,20472$ & 0,390669 \\
$\boldsymbol{\beta}_{5}$ & $2,15776 \mathrm{E}-06$ & 1,23468 & 0,186159 \\
$\boldsymbol{\beta}_{6}$ & $-5,33978 \mathrm{E}-07$ & $-0,37747$ & 0,371509 \\
\hline \hline
\end{tabular}

H. Pemodelan Geographically Weighted Poisson Regression (GWPR)

Geographically Weighted Poisson Regression (GWPR) merupakan pengembangan dari regresi Poisson. Model GWPR menggunakan pembobot geografis pada penaksiran parameternya. Matriks pembobot didapatkan dengan menggunakan pembobot fungsi Kernel fix Gaussian. Sehingga akan diperoleh parameter yang berbeda-beda untuk setiap kabupaten/kota di Jawa Timur.

\section{a. Pengujian Serentak}

Pengujian signifikasi model GWPR secara serentak bertujuan untuk mengetahui apakah secara serentak variabel prediktor memberikan pengaruh terhadap model.

Berdasarkan hasil pengujian dengan menggunakan software $R$ diperoleh nilai devians model GWPR sebesar 117,092477. Dengan taraf signifikansi 5\% didapatkan nilai tabel $\chi_{(0,05 ; 12)}^{2}=21,02607$ sehingga diputuskan Tolak $\mathrm{H}_{0}$ yang artinya paling tidak ada salah satu variabel prediktor yang berpengaruh signifikan terhadap variabel respon.

\section{b. Pengujian Parsial}

Pengujian parameter secara parsial digunakan untuk mengetahui parameter mana saja yang memberikan pengaruh yang signifikan terhadap variabel respon pada tiap-tiap lokasi.

Berdasarkan hasil pengujian parsial GWPR diketahui bahwa nilai parameter yang signifikan berbeda-beda setiap wilayah. Hasil estimasi dan nilai thit parameter GWPR dapat dilihat pada tabel output. Nilai thit parameter setiap kabupaten/kota dibandingkan dengan $t_{\text {tabel. }}$. Jika nilai $t_{\text {hit }}>t_{\text {tabel }}$ maka diputuskan Tolak $\mathrm{H}_{0}$, yang artinya variabel prediktor tersebut memberikan pengaruh terhadap model. Pengelompokan wilayah kabupaten/kota di Jawa Timur berdasarkan variabel yang signifikan disajikan dalam Gambar 3.

Hasil pengelompokan pertama menunjukkan bahwa semua variabel yang berpengaruh signifikan terhadap model untuk 13 kabupaten/kota di Jawa Timur. Sedangkan pada pengelompokan kedua dan seterusnya terdapat variabel yang tidak signifikan terhadap model. Setiap pengelompokan mempunyai anggota yang bervariatif antara satu sampai empat kabupaten/kota di Jawa Timur.

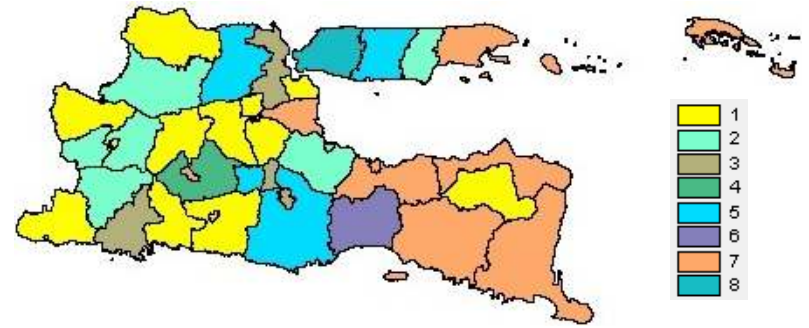

Gambar 3. Pengelompokan Berdasarkan Variabel yang Signifikan dengan Model GWPR

c. Contoh Interpretasi Salah Satu Model Kabupaten/Kota di Jawa Timur

Interpretasi model GWPR menggunakan lokasi ke-1 $\left(u_{1}, v_{1}\right)$ yaitu Kabupaten Pacitan dengan estimasi parameter. Disajikan juga pengujian parameter pada lokasi penelitian yang sama dengan contoh pemodelan metode GWPR. Berikut merupakan pengujian parameter model GWPR untuk Kabupaten Pacitan yang disajikan dalam Tabel 7.

Tabel 7. Pengujian Parameter Model GWPR di Kab. Pacitan

\begin{tabular}{crrr}
\hline \hline Parameter & \multicolumn{1}{c}{ Estimasi } & \multicolumn{1}{c}{$\mathbf{t}_{\text {(hit) }}$} & \multicolumn{1}{c}{$\boldsymbol{P}$-Value } \\
\hline $\boldsymbol{\beta}_{\mathbf{0}}$ & 4,801115 & 101,132189 & 0,000 \\
$\boldsymbol{\beta}_{\mathbf{1}}$ & 0,724379 & 7,791819 & 0,000 \\
$\boldsymbol{\beta}_{2}$ & $-0,08698$ & $-1,732542$ & 0,090 \\
$\boldsymbol{\beta}_{3}$ & 0,133426 & 2,618398 & 0,016 \\
$\boldsymbol{\beta}_{4}$ & $-0,62563$ & $-4,126346$ & 0,000 \\
$\boldsymbol{\beta}_{5}$ & 0,92036 & 18,629604 & 0,000 \\
$\boldsymbol{\beta}_{6}$ & $-0,17478$ & $-3,105829$ & 0,005 \\
\hline \hline
\end{tabular}

Karena semua nilai $\left|t_{\text {hitung }}\right|$ lebih besar dari $\mathrm{t}_{(\alpha / 2 ; 31)}$ maka dapat disimpulkan bahwa semua variabel signifikan. Model regresi yang dapat dibentuk untuk Kabupaten Pacitan dapat dilihat pada persamaan dibawah ini.

$$
\begin{aligned}
\ln (\widehat{\mu}) & =4,801115+0,724379 X_{2}-0,08698 X_{4}+0,133426 X_{9} \\
& -0,62563 X_{10}+0,92036 X_{12}-0,17478 X_{13}
\end{aligned}
$$

\section{Pemilihan Model Terbaik}

Pemilihan model terbaik berdasarkan kriteria AIC pada model regresi Poisson, regresi Binomial Negatif, GWNBR, dan GWPR disajikan pada Tabel 8.

\begin{tabular}{lr}
\multicolumn{2}{c}{ Tabel 8. Pemilihan Model Terbaik Dengan AIC } \\
\hline \hline Model & \multicolumn{1}{c}{ AIC } \\
\hline Regresi Poisson & 1317,20 \\
Regresi Binomial Negatif & 432,29 \\
GWNBR & 369,21 \\
GWPR & 614,37
\end{tabular}

Berdasarkan Tabel 8 menunjukkan bahwa dari keempat model yang terbentuk, GWNBR memiliki nilai AIC paling kecil dibandingkan dengan regresi Poisson, regresi binomial negatif, dan GWPR. Sehingga GWNBR lebih baik dalam 
memodelkan jumlah kasus property crime masing-masing Kabupaten/Kota di Provinsi Jawa Timur pada tahun 2017.

\section{KESIMPULAN DAN SARAN}

\section{A. Kesimpulan}

Kesimpulan yang didapatkan berdasarkan analisis yang telah dilakukan adalah Kota Surabaya memiliki jumlah kasus property crime paling banyak dengan jumlah 1466 kasus. Sedangkan Kabupaten Pacitan memiliki jumlah kasus property crime paling sedikit yaitu 33 kasus. Pada tahun 2017 jumlah kasus properti crime di Jawa Timur mencapai 7815 kasus dengan rata-rata sebanyak 206 kasus per kabupaten/kota. Jumlah kasus property crime memiliki standar deviasi yang besar yaitu 270,579 karena terdapat perbedaan yang signifikan antara jumlah kasus property crime pada setiap kabupaten/kota di Jawa Timur.

Hasil pemodelan dengan metode GWNBR terbentuk dua kelompok kabupaten/kota menurut variabel yang berpengaruh signifikan terhadap jumlah kasus property crime. Hasil pemodelan dengan metode GWPR menunjukkan bahwa kelompok kabupaten/kota menurut variabel yang berpengaruh signifikan terhadap jumlah kasus property crime sebanyak 16 kelompok. Kriteria AIC menunjukkan bahwa metode GWNBR merupakan metode yang paling sesuai untuk memodelkan jumlah kasus property crime setiap kabupaten/kota di Jawa Timur dibandingkan dengan metode regresi Poisson, regresi binomial negatif, dan GWPR.

B. Saran

Berdasarkan kesimpulan yang diperoleh, dapat dirumuskan saran sebagai pertimbangan penelitian selanjutnya adalah Pengelompokan kabupaten/kota berdasarkan variabel yang signifikan telah dibentuk sehingga diharapkan ke depannya ada usaha untuk menekan jumlah kasus property crime berdasarkan variabel yang signifikan di tiap lokasi. Untuk penelitian selanjutnya perlu adanya penambahan maupun evaluasi terhadap variabel prediktor yang memberikan pengaruh terhadap peningkatan jumlah kasus property crime di Jawa Timur. Selain itu, melakukan analisis dengan metode spasial yang lain, misalnya Mixed Geographically Weighted Negative Binomial Regression. Pembobot yang digunakan berbeda-beda, misalnya menggunakan fixed kernel dan adaptive kernel yang lain agar bisa dibandingkan untuk memperoleh model terbaik.

\section{DAFTAR PUSTAKA}

[1] T. Santoso, Kriminologi, Jakarta: Raja Grafindo Persada, 2001.

[2] L. Lochner, "Education, Work, and Crime: Theory and Evidence," University of Rochester Working Paper No. 465, pp. 1-34, 1999.
[3] Soekanto and Soerjono, Hukum Adat Indonesia, Jakarta: PT. Raja Grafindo Persada, 2001.

[4] G. S. Becker, "The Economic Way of Looking at Behavior," The Journal of Political Economy, pp. 385-409, 1993.

[5] E. H. Nassarudin, Kriminologi, Bandung: Pustaka Setia, 2016.

[6] Dobson, J. Annette and A. G. Barnett, An Introduction to Generalized Linear Models, Boca Raton, FL: Chapman \& Hall/CRC Press, 2008.

[7] A. S. Fotheringham, C. Brunsdon and M. Charlton, Geographically Weighted Regression, New York: John Wiley \& Sonc. Inc, 2002.

[8] A. Ricardo and T. Carvalho, Geographically Weighted Negative Binomial Regression-Incorporating Overdispersion, New York: Springer Science, 2013.

[9] R. Soesilo, Kriminologi, Bandung: PT. Karya Nusantara, 1985.

[10] A. O. Sullivan, Urban Economics. 5th Edition, New York: McGraw-Hill, 2003.

[11] B. Barus and U. S. Wirarisastra, Sistem Informasi Geografi; Sarana Manajemen Sumbedaya, Bogor: Laboraturium Pengindraan Jauh dan Kartografi Jurusan Tanah Fakultas Pertanian IPB, 2000.

[12] R. R. Hocking, Methods and Applications of Liner Models : Regression and the Analysis of Variance, New York: John Wiley and Sons, 1996.

[13] R. Walpole, R. Myers, S. Myers and K. Ye, Probability \& Statistics for Engineers \& Scientists (9th Edition), Boston: Prentice Hall, 2012.

[14] A. Agresti, An Introduction to Categorical Data Analysis (2nd Edition), Hoboken: John Wiley and Sons, 2007.

[15] A. C. Cameron and P. K. Trivedi, Regression Analysis of Count Data, Cambridge: Cambridge University Press, 1998.

[16] P. \&. N. J. A. McCullagh, Generalized linear models, London: Chapman and Hall, 1989.

[17] F. Famoye, J. T. Wulu and K. P. Singh, "On the Generalized Poisson Regression Model with an Application to Accident Data," Journal of Data Science 2 (2004), pp. 287-295, 2004.

[18] W. Greene, Functional Forms for the Negative Binomial Model for Count Data, Foundation, and Trends in Econometrics, New York: New York University, 2008.

[19] L. Anselin, Spatial Econometris : Methods and Models, Dordrecht: Kluwer Academic Publisher, 1988.

[20] Badan Pusat Statistik, "Badan Pusat Statistik," 14 November 2017. [Online].

Available:

https://www.bps.go.id/statictable/2009/02/21/1570/jumlahtindak-pidana-menurut-kepolisian-daerah-2000---2016.html. 